\title{
Phytochemical Screening for Various Secondary Metabolites, Antioxidant, and Anthelmintic Activity of Coscinium fenestratum Fruit Pulp: A New Biosource for Novel Drug Discovery
}

\author{
Coscinium fenestratum Meyvelerinin Farklı Sekonder Metabolitleri \\ Üzerinde Fitokimyasal Analiz Çalışmaları, Antioksidan ve Antihelmintik \\ Aktiviteleri: Yeni İlaçların Keşfinde Yeni Bir Doğal Kaynak
}

\author{
(D) Kuntal DAS ${ }^{1 *}$, (D) Raman DANG ${ }^{1}$, (D) Gokul SIVARAMAN², (D) Rajasekharan Punathil ELLATH³ \\ 'Krupanidhi College of Pharmacy, Department of Pharmacognosy, Bangalore, India \\ ${ }^{2}$ National Post Doctoral Fellowship (N-PDF), Cimap Research Centre, Bangalore, India \\ ${ }^{3}$ Principal Scientist, Division of Plant Genetic Resources, Bangalore, India
}

\begin{abstract}
Objectives: Coscinium fenestratum (Gaertn.) Colebr. (CF, Family: Menispermaceae) is an important endangered woody climber in India. CF contains various major secondary metabolites for the treatment of various disease conditions. The present study aimed to establish the antioxidant and anthelmintic activity of Coscinium fenestratum fruit pulp.

Materials and Methods: The dried fruit pulp was subjected to aqueous, methanol, and mixed aqueous and methanol (1:1) solvent extraction followed by phytochemical investigations, estimations of alkaloids, phenolics, flavonoids, antioxidant potentiality (DPPH and hydrogen peroxide scavenging methods), and anthelmintic activity tests were carried out.

Results: Preliminary phytochemical screening of CF fruit extracts revealed the presence of alkaloids phenols, flavonoids, tannins, steroids, and resins, which are responsible for biologic properties. The combined aqueous and methanol extract resulted in significant anthelmintic and antioxidant properties in a dose-dependent manner. The DPPH free radical scavenging assay and $\mathrm{H}_{2} \mathrm{O}_{2}$ assay exhibited IC $\mathrm{C}_{50}$ values of $42.38 \pm 0.012$ $\mu \mathrm{g} / \mathrm{mL}$ and $46.80 \pm 0.011 \mu \mathrm{g} / \mathrm{mL}$, respectively. Thereafter, the anthelmintic activity test was carried out against Pheretima posthuma and Taenia solium with the extract at varying concentrations of $25,50,100$ and $150 \mathrm{mg} / \mathrm{mL}$ and compared with standard albendazole (25 and $50 \mathrm{mg} / \mathrm{mL})$ and saline $(0.9 \%)$ as a control. All the extracts exhibited concentration-dependent paralytic effect, followed by death on the test organism, but significant activity was observed with the combined methanol and aqueous extract.

Conclusion: The study was conducted in order to find possible isolated compounds as a biosources for future novel antioxidants in food and pharmaceutical formulations. Our findings indicate for the first time that the CF fruit pulp has therapeutic values with prominent antioxidant and anthelmintic properties.
\end{abstract}

Key words: Antioxidant study, anthelmintic activity, Coscinium fenestratum, extracts, phytochemical study

Öz

Amaç: Coscinium fenestratum (Gaertn.) Colebr. (CF, Familya: Menispermaceae) Hindistan'da önemli bir odunsu bitkidir. Bitki çeşitli hastalıkların tedavisinde etkili olan çeşitli majör sekonder metabolitler içermektedir. Bu çalışmada, Coscinium fenestratum meyvelerinin antioksidan ve antihelmintik aktiviteleri değerlendirilmiştir.

Gereç ve Yöntemler: Bu çalışmada, kurutulmuş meyvelerin sulu, metanollü ve sulu metanollü (1:1) ekstreleri hazırlanmış ve ekstrelerin alkaloit, fenolik, flavonoid içerikleri ile antioksidan (DPPH ve hidrojen peroksit süpürücü etki tayin yöntemi) ve antihelmintik aktiviteleri değerlendirilmiştir.

*Correspondence: E-mail: drkkdsd@gmail.com, Phone: +919632542846 ORCID-ID: orcid.org/0000-0001-6118-5270

Received: 12.05.2017, Accepted: 03.08.2017

-Turk J Pharm Sci, Published by Galenos Publishing House. 
Bulgular: Ön fitokimyasal tarama çalışmaları, CF meyve ekstrelerinin biyolojik etkiden sorumlu alkaloitler, fenoller, flavonoidler, tanenler, steroidler ve reçine içerdiğini ortaya koymuştur. Sulu metanollü ekstrenin doz bağımlı olarak anlamlı derecede antihelmintik ve antioksidan etkiye sahip olduğu belirlenmiștir. DPPH serbest radikal süpürücü aktivite tayini ve $\mathrm{H}_{2} \mathrm{O}_{2}$ deneyinde $\mathrm{IC}_{50}$ değerleri sırasıyla $42.38 \pm 0.012 \mu \mathrm{g} / \mathrm{mL}$ ve $46.80 \pm 0.011$ $\mu \mathrm{g} / \mathrm{mL}$ olarak belirlenmiștir. Antihelmintik aktivite, Pheretima posthuma ve Taenia solium'a karșı ekstrenin $25,50,100$ ve $150 \mathrm{mg} / \mathrm{mL}$ gibi değișen konsantrasyonlarında, standart albendazol ( 25 and $50 \mathrm{mg} / \mathrm{mL}$ ) ve kontrol olarak kullanılan tuzlu suya (\%0.9) kıyasla denenmiștir. Tüm ekstreler doz bağımlı paralitik etki göstermiş, organizmalar üzerinde anlamlı derecede öldürücü etki, sulu metanollü ekstre için tespit edilmiştir.

Sonuç: Bu çalışmanın bulguları, CF meyve ekstresinin antioksidan ve antihelmintik etkileri ile tedavi edici etkiye sahip olduğunu ilk defa göstermiş, izole edilen bileşiklerin gıda ve farmasötik formülasyonlarda yeni antioksidan doğal kaynaklar olarak kullanılabileceğini ortaya koymuştur.

Anahtar kelimeler: Antioksidan çalışma, antihelmintik etki, Coscinium fenestratum, ekstreler, fitokimyasal çalışma

\section{INTRODUCTION}

Secondary metabolites are important plant constituents for effective therapeutic activities. It was reported that the presence of this specific group of compounds showed specific medicinal actions and sometimes traditionally reported, but there is little by way of scientific validation. Among these activities, antioxidant and anthelmintic activities are very important. Rapid production of free radicals leads to oxidative damage to biomolecules and results in serious disorders viz. degenerative disorders, cancer, diabetes, neural disorders, and ageing, and hence antioxidant plays a vital role to block free radical production.1.2 Moreover, infections with parasitic worms are serious problems for humans, producing various diseases worldwide, and helminthes is one of them. There are various types of worms viz. round worms or nematodes including intestinal worms, filarial worms that cause lymphatic filariasis, chocerciasis, platyhelminths or flatworms including flukes, and tapeworms. ${ }^{3}$ These worms cause lymphatic filariasis, onchocerciasis, cysticercosis, malnutrition, anemia, eosinophilia, and pneumonia, which are life-threatening. As per the report of the World Health Organization, more than two billion people have parasitic worm infections globally. ${ }^{4}$ Treatment with synthetic drugs causes many adverse effects and helminthes become resistant. Hence, there are demands for natural plant secondary metabolites in the treatment and prevention of this chronic problem.

Coscinium fenestratum (Gaertn.) Colebr. (CF) is a woody climber that belongs to the family Menispermaceae. The plant is commonly known as tree turmeric or false Calumbadue due to its yellow stem. CF is found in Asian countries such as India, Malaysia, Vietnam, Myanmar, Singapore, Thailand, and Sri Lanka. ${ }^{5,6}$ In India, the plant is endangered and located in the Western Ghats areas, especially in high rainfall evergreen forests of Karnataka, Kerala, and Tamil Nadu at altitudes of 500$750 \mathrm{~m} .{ }^{7.8}$ The tree requires long seed germination times and takes 14-15 years to mature and flower. Hence, the fruits and seeds are very rare and this leads to endangered red- labeled species due to over exploitation from natural habitats, zero cultivation planning, and trees being uprooted before their reproduction stage for their medicinal importance. ${ }^{4}$ The leaves and roots are traditionally used for the treatment of ulcers, skin diseases, eye disorders, inflammation, hypertension, jaundice, diabetes, and snake bites. ${ }^{9-11}$ Multiple beneficial pharmacologic-related properties with various solvent extracts of the leaves and roots of CF have been reported viz. hepatoprotective, immune protective, hypoglycemic, anti-tumor activities, dressing wounds, ulcer treatment, and for cutaneous leishmaniasis, and it is non-toxic to mammals. ${ }^{12,13}$ Stem and root extracts have also shown antioxidant and antimicrobial potential. ${ }^{14}$ Traditionally CF is used as one of the ingredients in several ayurvedic preparations such as soap, bath gels, face wash and bath oil, and in the cosmetic industry as facial masks, fairness creams, and body lotions. ${ }^{4}$ Furthermore, stem extract of $\mathrm{CF}$ was reported to have a significant effect on stimulating insulin secretion. ${ }^{15}$ These activities are due to the presence of the important alkaloid-containing phytoconstituents such as berlambine, dihydroberlambine, noroxyhydrastine, berberine(an isoquinoline alkaloid) and other constituents such asceryl-alcohol, saponin, hentriacontane, sitosterol glucoside, palmitic acid, and oleic acid, which are isolated from the stem and roots of the plants. ${ }^{16}$ Recently ecdysterone was identified and isolated from the stem and leaves of CF and evaluated using high-performance liquid chromatography and liquid chromatography-mass spectrometry.17 The availability of various phytoconstituents in fruits is unknown and hence it is required to select the various solvent extractions for the fruits for further processing. It was reported that the constituents varied with solvent extraction and the zone of collection of the raw materials. ${ }^{18-20}$ Till now, no literature has revealed the medicinal importance of the fruit and the pulp constituents, perhaps due to improper collection or the low availability of the fruits and seeds. It is also essential to understand the cause of delayed germination. Based on the availability of secondary metabolites in the plant, the present study was conducted to determine and evaluate the phytoconstituents present and novel antioxidant and anthelmintic activities were assessed for the first time from various extracts of the dried fruit pulp.

\section{MATERIALS AND METHODS}

\section{Collection and identification of fruits}

One hundred CF fruits were collected from Dr. Gokul S, CIMAP Research Centre, Allalasandra, GKVK Post, Bangalore -65 (Latitude: $12^{\circ} 58^{\prime} \mathrm{N}$ and Longitude: $77^{\circ} 38^{\prime} \mathrm{E}$ ), and authenticated by Dr. P.E. Rajasekharan, Principal Scientist, IIHR, Bangalore. The fruits are stored as herbarium in Pharmacognosy Department of Krupanidhi College of Pharmacy, Bangalore (Herbarium No: CF-317/KCP/2016-17).

\section{Morphological study of fruits and seeds}

Fifty fruits were randomly selected and measured for diameter using Vernier calipers with the measurement readings in centimeters $(\mathrm{cm})$, with precision up to 2 decimal places. 
Thereafter, seed diameters were also measured after removal of pulp and resinous matter to understand the probability for late germination. In addition, a complete morphologic study was performed, observing color, odor, size, shape, and extra features.

\section{Preparation of extracts}

Fresh fruits of the CF plant were shade-dried for several days and in between observed for fungal infections. The dried pulps were ground to a course powder and $250 \mathrm{~g}$ of the same underwent soxhlet extraction with light petroleum ether for 4 hrs and defatting the materials. The pulps were successively extracted with four solvents viz. chloroform, methanol (80\%), aqueous, and an equal ratio mixture of aqueous and methanol (80\%) (1:1). The reflux method was used for all extracts separately for 7-8 hrs (after drying after each extraction) preparation and finally the yield was calculated after removal of the solvents by rotary evaporation (at $45^{\circ} \mathrm{C}$ ) and the dried extract was stored in a refrigerator (at $4-5^{\circ} \mathrm{C}$ ) for further investigations.

\section{Phytochemical screening}

The preliminary phytochemical analysis of the plant extracts was performed using the standard protocol as describe by Khandelwal ${ }^{21}$, and Kokate ${ }^{22}$, to identify the presence of alkaloids, flavonoids, steroids, glycosides, cardiac glycosides, anthraquinones, tannins, and saponins.

Based on the presence of phytoconstituents, the following estimations of secondary metabolites were carried out:

\section{Determination of alkaloid}

Onemilligram of each plant extract was dissolved separately in dimethyl sulphoxide and $1 \mathrm{~mL}$ of $2 \mathrm{~N} \mathrm{HCl}$ was added and filtered. The solutions were transferred to a separating funnel with the addition of $5 \mathrm{~mL}$ of Bromocresol green solution and $5 \mathrm{~mL}$ of phosphate buffer. The mixture was then shaken thoroughly with $1,2,3$, and $4 \mathrm{~mL}$ of chloroform and collected in a $10-\mathrm{mL}$ volumetric flask and diluted to volume with chloroform. A set of reference standard solutions of atropine $(10,20,30,40,50$ and $60 \mu \mathrm{g} / \mathrm{mL}$ ) were prepared in the same manner. The absorbances for the test and standard solutions were determined using an ultraviolet (UV) spectrophotometer at $470 \mathrm{~nm}$. A blank sample was prepared for error correction. Finally, the total alkaloid content was calculated as $\mathrm{mg}$ of atropine equivalent $(A E) / g$ of each extract. ${ }^{23}$

\section{Total phenolic content}

The total phenolic compounds in all three fruit pulp extracts of CF were determined using Folin-Ciocalteu's method. A blue color is formed during the reaction, which is measured spectrophotometrically. ${ }^{24}$ One milliliter of sample $(1 \mathrm{mg} / \mathrm{mL})$ was mixed with $1 \mathrm{~mL}$ of Folin-Ciocalteu's phenol reagent. After $5 \mathrm{~min}, 10 \mathrm{~mL}$ of a $7 \% \mathrm{Na}_{2} \mathrm{CO}_{3}$ solution was added to the mixture, then $13 \mathrm{~mL}$ of deionized distilled water was added and mixed thoroughly. The mixture was kept in the dark for $90 \mathrm{~min}$ at $23^{\circ} \mathrm{C}$ for the reaction (blue color formation). Gallic acid was used as a standard and the standard solution was prepared as per the same method followed for the sample $(10,20,30,40,50$ and $60 \mu \mathrm{g} / \mathrm{mL}$ ). Then, absorbance was taken at $765 \mathrm{~nm}$. The total phenolic content was determined from extrapolation of a calibration curve, which was made by preparing a gallic acid solution, and was expressed as $\mathrm{mg}$ of gallic acid equivalent (GAEs) per $g$ of extract ( $G A \mathrm{mg} / \mathrm{g}$ ). The estimation of the phenolic compounds was carried out in triplicate. The following formula was used for the calculation:

$\mathrm{T}=(\mathrm{C} \times \mathrm{V}) / \mathrm{M}$

Where, $\mathrm{T}=$ total content of phenolic compounds, $\mathrm{mg} / \mathrm{g}$ plant extract, in GAE; $C=$ concentration of gallic acid established from the calibration curve $(\mu \mathrm{g} / \mathrm{mL}) ; \mathrm{V}=$ volume of extract $(\mathrm{mL})$; $\mathrm{M}=$ weight of water extract of the plant $(\mathrm{g})$.

\section{Total flavonoid content}

The total flavonoid content was measured using an aluminum chloride colorimetric assay as described by Park et al. ${ }^{25}$ In a $10-\mathrm{mL}$ test tube, $0.3 \mathrm{~mL}$ of extracts, $3.4 \mathrm{~mL}$ of $30 \%$ methanol, $0.15 \mathrm{~mL}$ of $\mathrm{NaNO}_{2}(0.5 \mathrm{M})$, and $0.15 \mathrm{~mL}$ of $\mathrm{AlCl}_{3} \cdot 6 \mathrm{H}_{2} \mathrm{O}(0.3 \mathrm{M})$ were mixed thoroughly. After a few min, $1 \mathrm{~mL}$ of $\mathrm{NaOH}$ (1 M) was added. In the same way, the standard solution was also prepared using rutin (Ru) as a standard. The standard curve for total flavonoids was made using a Ru standard solution (10, 20, $30,40,50$ and $60 \mu \mathrm{g} / \mathrm{mL}$ ). The solution was mixed well and the absorbance was measured against the reagent blank at $506 \mathrm{~nm}$. The total flavonoids were expressed as $\mathrm{mg}$ of $\mathrm{Ru}$ equivalent/g of dried extract.

\section{Antioxidant assays}

Each sample was dissolved in $80 \%$ methanol to make a concentration of $1 \mathrm{mg} / \mathrm{mL}$ and then diluted to prepare the series concentrations for antioxidant assays.

\section{1,1-diphenyl-2-picryl-hydrazyl (DPPH) assay}

All the fruit pulp extracts were tested for their free radical scavenging activity against the stable free radical DPPH. The ability to bleach DPPH by the extracts was quantified using a spectrophotometer. The method used was as described by Brand-Williams et al. ${ }^{26}$ One milliliter of $0.1 \mathrm{mM} \mathrm{DPPH}$ solution in methanol was mixed with $1 \mathrm{~mL}$ of plant extract solution of varying concentrations $(25,50,100,150$, and $200 \mu \mathrm{g} /$ $\mathrm{mL}$ ). Corresponding blank samples were prepared using a mixed $1 \mathrm{~mL}$ methanol and $1 \mathrm{~mL}$ DPPH solution, methanol and $\mathrm{L}$-ascorbic acid was used as reference standard $(1-100 \mu \mathrm{g} / \mathrm{mL})$ and the experiment was performed in triplicate. The decrease in absorbance was measured at $517 \mathrm{~nm}$ after $30 \mathrm{~min}$ in the dark (for the reaction) using a UV-Vis spectrophotometer. The percentage scavenging was calculated using the following formula:

DPPH scavenging effect $(\%)=\left[\left(A_{\text {control }}-A_{\text {sample }} / A_{\text {control }}\right) \times 100\right]$

The $I_{50}$ value of the sample i.e. the concentration of sample required to inhibit $50 \%$ of the DPPH free radical, was calculated using the calibration curve by linear regression.

\section{Hydrogen peroxide-scavenging activity:}

The hydrogen peroxide assay was as described by Nabavi et al. ${ }^{27}$ Hydrogen peroxide solution ( $2 \mathrm{mmol} / \mathrm{L}$ ) was prepared in phosphate buffer $(\mathrm{pH} 7.4)$. Extract $(0.6 \mathrm{~mL})$ at various 
concentrations $(25,50,100,150$ and $200 \mu \mathrm{g} / \mathrm{mL})$ was added to hydrogen peroxide solution. For each concentration, a separate blank sample was prepared. The absorbance of hydrogen peroxide with a UV visible spectrometer at $230 \mathrm{~nm}$ was determined after $10 \mathrm{~min}$, and then readings were calculated for the blank solution containing phosphate buffer without hydrogen peroxide. The percentage inhibition of $\mathrm{H}_{2} \mathrm{O}_{2}$ scavenging activity was calculated using the formula below:

$\%$ Scavenging activity $=[1$ - (Absorbance of test / Absorbance of control)] $\times 100$

\section{Anthelmintic property}

\section{Chemicals and drugs}

All chemicals and drugs were obtained commercially and were of analytical grade. Albendazole was purchased from the local market of Bangalore. Dimethyl formamide (DMF) were purchased from Merck, Germany.

\section{Selection of experimental organisms}

The preliminary assay was performed on adult earthworm, Pheretima posthuma, belong to class Oligochaeta. Due to its easy availability and its anatomic and physiologic resemblance with intestinal round worm parasites of humans, they have been widely used for preliminary evaluations of anthelmintic activity. The experiment was conducted after ethics clearance was obtained from the Institutional Animal Ethics Committee of Krupanidhi College, Bangalore (Approval no: KCP/ PCOL/5/2017/). Thereafter, tapeworm (Taenia solium, Family: Taeniidae) was selected for assurance of anthelmintic activity. Earth worms were collected from moist soil of the medicinal garden of Krupanidhi College of Pharmacy, Bangalore, and tape worms were collected from a local slaughter house (infested intestines of pigs), Yeshwanthpur, Bangalore. Both were separately washed with normal saline to remove all foreign matter from the body and later used for the anthelmintic study. Earthworms of $3-5 \mathrm{~cm}$ in length and $0.1-0.2 \mathrm{~cm}$ in width, and tapeworms of $6-8 \mathrm{~cm}$ in length were used for the entire experimental protocol. Albendazole ( $25 \mathrm{mg} / \mathrm{mL}$ and $50 \mathrm{mg} / \mathrm{mL}$ ) was used as a standard solution (prepared by dissolved in DMF) and each test solution of the CF fruit extracts $(25,50,100$ and $150 \mathrm{mg} / \mathrm{mL}$ ) was evaluated for anthelmintic activity.

\section{Methods}

For the evaluation of each plant extract, four worms were placed in separate Petri dishes containing $20 \mathrm{~mL}$ solution of crude extracts in the said concentrations and then the worms were introduced to the solutions. The same method was used for each case.

\section{Observations}

Observations were made for the time taken for paralysis and death of individual worms during the completion of the investigation. When there was no movement of any part of the body, the time was noted for the paralysis condition, followed by the death time, which was noted when no movement of any part of the body even after being shaken vigorously, and also followed by fading of the body colors of the worms. Death was also ascertained when the worms were dipped in warm water at $50^{\circ} \mathrm{C} .{ }^{28}$ The experiment was carried out as per the guidelines of the Institutional Biosafety and Ethics Committee. ${ }^{29}$

\section{Statistical analysis}

Data are expressed as mean \pm SD from three replications. For antioxidant assays and anthelmintic activity, the one-way ANOVA test followed by Tukey's test ( $p<0.05)$ was used to analyze the differences among $I C_{50}$ of the various extracts for different antioxidant assays. The $\mathrm{IC}_{50}$ values were determined using the Graph Pad Prism 5 software. Correlation coefficient ( $r$ ) was calculated for the extract and the activities. $P$ values less than 0.05 were considered statistically significant.

\section{RESULT AND DISCUSSION}

\section{Morphologic study of the fruits and seeds}

Vernier calipers were used to measure the diameter (50 measurements) of CF fruits and seeds separately (Figures 1 and 2) and the diameters were recorded (Table 1 and 2, respectively). The color of the fruits (Figure 3) was greyish ash and there was no odor. The sizes ranged from $10-14 \mathrm{~cm}$ in diameter and the shape was globulus, tapering towards the embryonic site. Each fruit contained a single seed. The fruit pulp was made up of resinous matter (Figure 1). In contrast, the color of the seeds was off-white to gray; the seeds also had no odor. The seeds were $4-6 \mathrm{~cm}$ in diameter and sub globular-

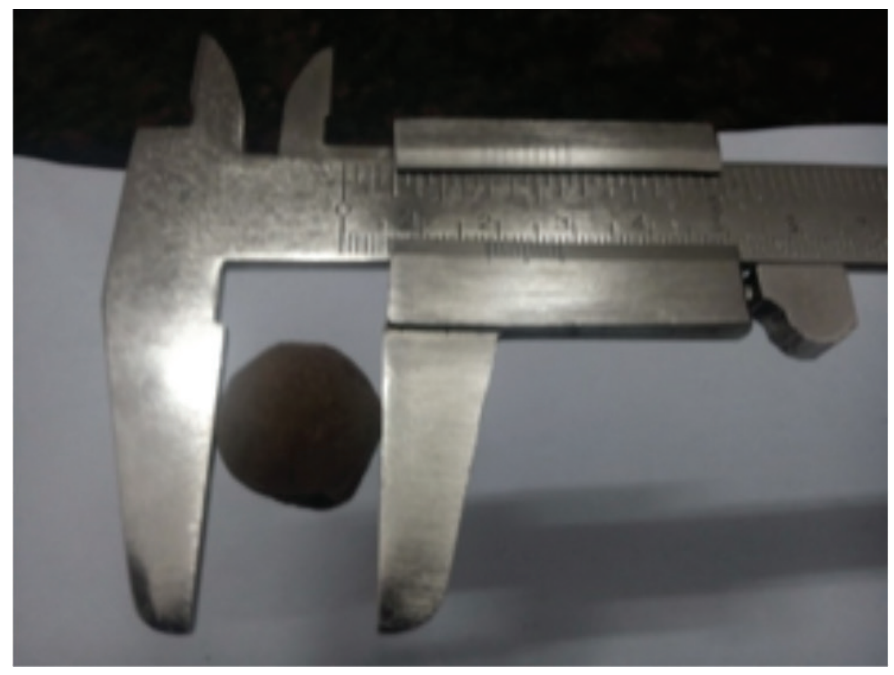

Figure 1. Measurement of $\mathrm{CF}$ fruit

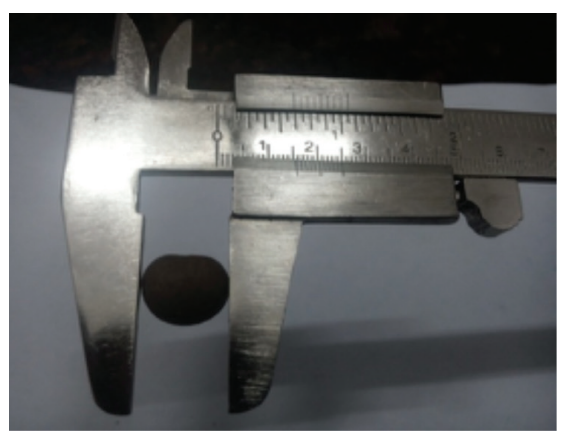

Figure 2. Measurement of CF seed 
shaped, divaricate. The seeds were very hard to break (Figure 4). The high content of alkaloids i.e. berberine in the seed and fact that the embryonic opening part was closed by resinous matter were considered to cause the delayed germination. The average diameter of fruit was $12.35 \mathrm{~cm}$; the minimum diameter of fruit was $10.6 \mathrm{~cm}$; and the maximum diameter of fruit was $13.7 \mathrm{~cm}$. The average seed diameter was $5.03 \mathrm{~cm}$; the minimum

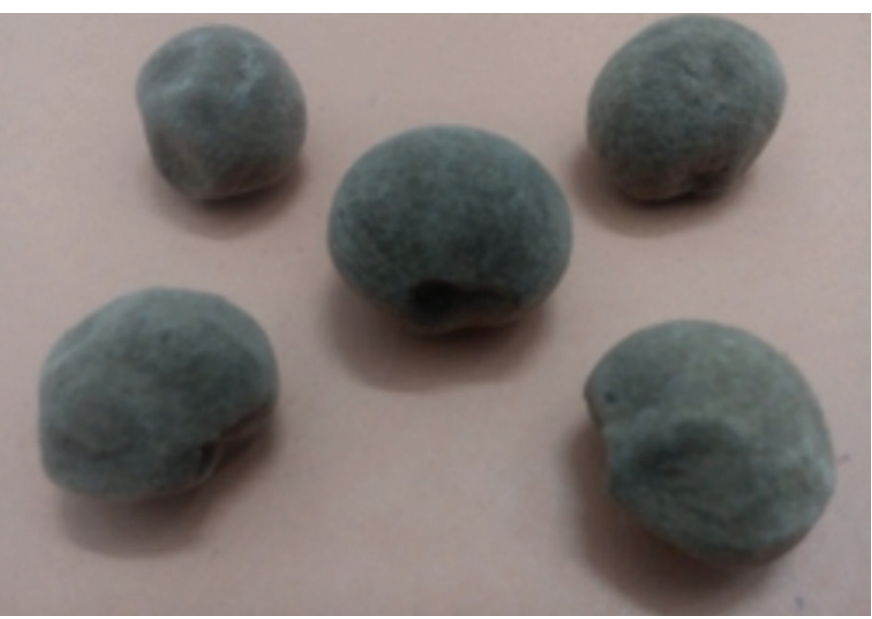

Figure 3. Fruits of CF
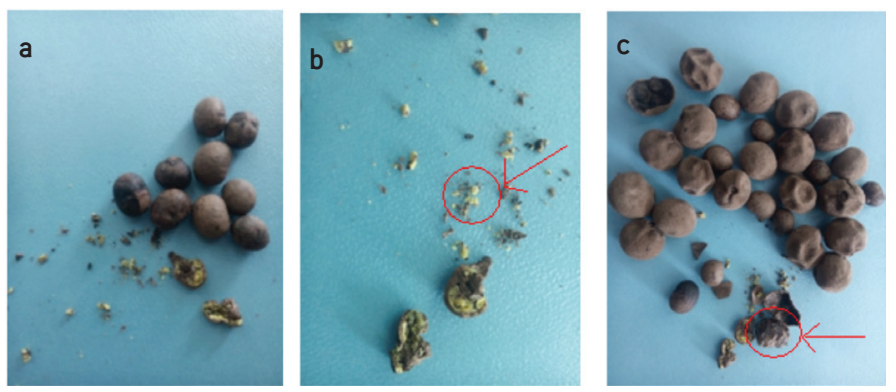

Figure 4. Seeds of CF a) Seeds without resinous mass, b) Broken seed with yellow berberine, c) Seeds surrounded by resinous mass seed diameter was $4.1 \mathrm{~cm}$; and the maximum seed diameter was $6.3 \mathrm{~cm}$.

\section{Extract yield:}

The yield and color of the crude extract obtained from the extracted fruit pulp of CF are depicted in Table 3 and Figures 5 and 6 . The yield of the extracts was found at a higher percentage $(5.76 \%)$ in the combined extract of methanol and aqueous solvents, followed by the methanol (5.12\%) and aqueous (4.12\%) extracts. Earlier literature are also reported that combined extracts increased the yield of the crude extracts more than the individual extract in particular plant species. ${ }^{19,30}$

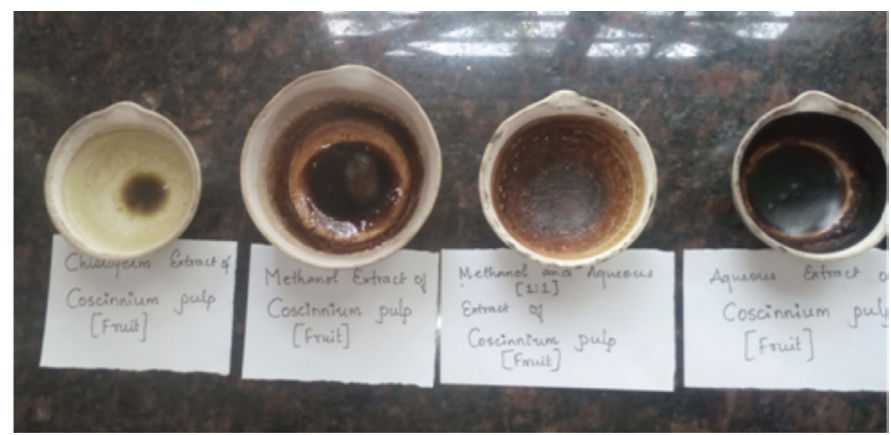

Figure 5. Various CF fruit pulp extracts

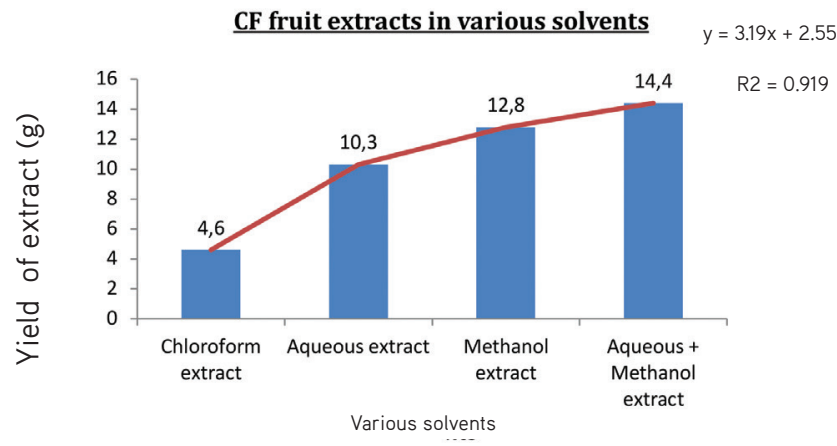

Figure 6. Yield of crude extracts of CF fruits in various solvents

Table 1. CF Fruit diameter (50 measurements) determination

\begin{tabular}{|c|c|c|c|c|c|c|c|c|c|}
\hline SI No. & Diameter $(\mathrm{cm})$ & SI No. & Diameter $(\mathrm{cm})$ & SI No. & Diameter $(\mathrm{cm})$ & SI No. & Diameter $(\mathrm{cm})$ & SI No. & Diameter $(\mathrm{cm})$ \\
\hline 1 & 12.5 & 11 & 12.4 & 21 & 12.4 & 31 & 12.6 & 41 & 11.7 \\
\hline 2 & 11.7 & 12 & 12.7 & 22 & 12.6 & 32 & 13.2 & 42 & 11.4 \\
\hline 3 & 13.2 & 13 & 12.3 & 23 & 13.7 & 33 & 13.2 & 43 & 10.9 \\
\hline 4 & 12.7 & 14 & 11.5 & 24 & 13.2 & 34 & 11.5 & 44 & 10.9 \\
\hline 6 & 13.1 & 16 & 13.2 & 26 & 11.6 & 36 & 11.4 & 46 & 12.5 \\
\hline 7 & 13.4 & 17 & 11.8 & 27 & 11.5 & 37 & 12.4 & 47 & 10.6 \\
\hline 8 & 11.6 & 18 & 13.6 & 28 & 11.8 & 38 & 12.5 & 48 & 11.8 \\
\hline 9 & 11.4 & 19 & 13.2 & 29 & 12.1 & 39 & 12.5 & 49 & 11.6 \\
\hline
\end{tabular}

Each fruit diameter was determined using Vernier calipers 


\begin{tabular}{|c|c|c|c|c|c|c|c|c|c|}
\hline SI No. & Diameter $(\mathrm{cm})$ & SI No. & Diameter $(\mathrm{cm})$ & SI No. & Diameter $(\mathrm{cm})$ & SI No. & Diameter $(\mathrm{cm})$ & SI No. & Diameter $(\mathrm{cm})$ \\
\hline 1 & 4.1 & 11 & 5.3 & 21 & 5.3 & 31 & 4.6 & 41 & 4.8 \\
\hline 2 & 4.7 & 12 & 5.5 & 22 & 5.2 & 32 & 4.5 & 42 & 6.1 \\
\hline 3 & 5.6 & 13 & 4.7 & 23 & 5.1 & 33 & 4.5 & 43 & 6.1 \\
\hline 5 & 4.1 & 15 & 4.6 & 25 & 4.5 & 35 & 6.2 & 45 & 5.6 \\
\hline 6 & 5.3 & 16 & 4.2 & 26 & 4.3 & 36 & 5.5 & 46 & 5.3 \\
\hline 7 & 5.4 & 17 & 5.3 & 27 & 4.7 & 37 & 5.4 & 47 & 4.9 \\
\hline 8 & 5.6 & 18 & 6.1 & 28 & 4.7 & 38 & 5.3 & 48 & 4.7 \\
\hline
\end{tabular}

Each seed diameter was determined using Vernier calipers

Table 3. Yield and color of extracts of CF fruit pulps

\begin{tabular}{lll} 
Different extracts & \% Yield & Color of extract \\
\hline Chloroform & 1.84 & Pale greenish Ash \\
\hline Methanol (80\%) & 5.12 & Medium to dark brown \\
\hline Aqueous & 4.12 & Dark brownish grey \\
\hline $\begin{array}{l}\text { Aqueous + methanol } \\
\text { (80\%) (1:1) }\end{array}$ & 5.76 & Light to medium dark brown \\
\hline
\end{tabular}

\section{Table 4. Various chemical tests for CF fruit pulp extracts}

\begin{tabular}{lllll}
\hline & \multicolumn{2}{l}{ Different extracts } & \\
\hline & Chloroform & Methanol & Aqueous & $\begin{array}{l}\text { Aqueous }+ \\
\text { methanol (1:1) }\end{array}$ \\
\hline Protein & + & -- & -- & -- \\
\hline Carbohydrate & -- & -- & -- & -- \\
\hline Lipid & + & -- & -- & -- \\
\hline Alkaloids & -- & + & + & ++ \\
\hline Glycosides & -- & + & + & ++ \\
\hline Tannins & -- & + & + & ++ \\
\hline Flavonoids & -- & + & -- & ++ \\
\hline Saponin & -- & + & + & + \\
\hline Resin & + & + & -- & + \\
\hline Steroids & -- & -- & -- & -- \\
\hline Phenols & -- & + & + & ++ \\
\hline
\end{tabular}

$(--)=$ Negative test $;(+)=$ Positive test

The present investigation also resulted similarly. This indicated that the CF fruit pulp extracts was also dependent on the type of solvent used. A literature survey revealed that the extraction yield increases with the increasing polarity of the solvent used in extraction. Hence, the combined use of water and organic
Table 5. Content of total alkaloids in CF fruit pulp extracts

\begin{tabular}{ll} 
Extracts & Alkaloid content $(\mathrm{mg}$ of $\mathrm{AE} / \mathrm{g})$ \\
\hline Methanol extract & $68.20 \pm 0.025^{\star \star}$ \\
\hline Aqueous extract & $41.01 \pm 0.015^{\star \star}$ \\
\hline Aqueous + methanol extract & $77.02 \pm 0.020^{\star *}$ \\
\hline
\end{tabular}

Mean \pm SD ( $n=3)$; One-way ANOVA study followed by Tukey's post test. Significance level, ${ }^{\star *} p<0.05$. AE: Atropine equivalent

solvent may facilitate the extraction of soluble chemicals in water and/or organic solvent, and accordingly, the yield of secondary metabolites is higher than with individual solvent extraction. ${ }^{31}$ The results of this study are in agreement with the extraction yields of some medicinal plants. ${ }^{32,33}$

\section{Phytochemical screening}

Various chemical tests were performed to detect the presence of secondary metabolites. The results are tabulated in Table 4. Based on the availability of the secondary metabolites, further estimation of the plant's vital constituents viz. total alkaloids, phenols, and total flavonoid were determined for methanol, aqueous, and combined aqueous and methanol extracts.

\section{Total alkaloids}

The alkaloid content was determined in CF fruit pulp extracts and expressed in terms of $A E$ as $\mathrm{mg}$ of $\mathrm{AE} / \mathrm{g}$ of extract (standard curve equation: $y=0.014 x+0.106, R^{2}=0.994$ ). The highest concentration of alkaloid was measured as $77.02 \mathrm{mg} / \mathrm{g}$ in the combined extract. This is because of the high solubility of the alkaloids in the combined extract rather than in individual extracts (Table 5). ${ }^{31,33}$

\section{Total phenolic content}

The total phenolic content in the entire extracted CF fruit pulp was determined using Folin-Ciocalteu's reagent and is expressed in terms of GAEs (mg of GA/g of extract, standard curve equation: $\left.y=0.012 x+0.166, R^{2}=0.991\right)$. The highest 
concentration of phenols was measured in the combined aqueous and methanol extract, followed by the methanol and aqueous extract. It was reported that high solubility of phenols in polar solvents provides high concentrations in extracts, ${ }^{34,35}$ and the same trend followed in the present investigation where combined aqueous and methanol solvents increased the solubility of phenolic compounds more than with individual solvents (Table 6).

\section{Total flavonoid content}

The concentration of flavonoids was determined using spectrophotometry for all three extracts and the content of flavonoids is expressed in terms of Ru equivalent (mg of Ru/g, the standard curve equation: $\left.y=0.011 x+0.041, R^{2}=0.993\right)$. In this case, the same trend also followed as above. The highest flavonoid concentration ( $98.03 \mathrm{mg} \mathrm{Ru} / \mathrm{g}$ ) was recorded for the combined extract, followed by the methanol extract. This result was due to the solubility. It was reported that the concentration of flavonoid in plant extracts depends on the polarity of solvents used in the extract preparation. ${ }^{36}$ A similar result was obtained in this study (Table 7).

Based on the estimation of total alkaloids, phenols, and flavonoids, a further investigation was carried out to reveal an antioxidant study. Phenolic and flavonoid compounds are known to have a correlation with antioxidant activities. ${ }^{37,38}$ The present study revealed the higher content of these compounds, and due to their presence, the CF fruit pulp may have scavenging activity i.e. mainly due to their redox properties, which play an important role in adsorbing and neutralizing free radicals and decomposing peroxides. ${ }^{39}$ In view of this, two different methods were used to reveal antioxidant activity.

\section{Antioxidant assays}

An antioxidant is defined as any substance that inhibits oxidative damage to a target molecule. ${ }^{40}$ Antioxidant compounds such as phenolic acids, polyphenols, and flavonoids reduce free radicals such as peroxide, hydrogen peroxide or lipid peroxyl,

\section{Table 6. Content of total Phenolics in CF fruit pulp extracts}

\begin{tabular}{ll}
\hline Extracts & Phenolic content (mg of GA/g) \\
\hline Methanol extract & $56.12 \pm 0.015^{\star *}$ \\
\hline Aqueous extract & $43.22 \pm 0.020^{\star *}$ \\
\hline Aqueous + Methanol extract & $69.13 \pm 0.188^{* *}$ \\
\hline
\end{tabular}

Mean \pm SD (n=3); One-way ANOVA study followed by Tukey's post test.

Significance level, ${ }^{\star *} p<0.05$. GA: Gallic acid

Table 7. Content of total Flavonoids in CF fruit pulp extracts

\begin{tabular}{ll} 
Extracts & Flavonoids content (mg of RuE/g) \\
\hline Methanol extract & $36.02 \pm 0.021^{\star \star}$ \\
\hline Aqueous extract & $24.12 \pm 0.020^{\star \star}$ \\
\hline Aqueous + methanol extract & $48.22 \pm 0.015^{\star *}$ \\
\hline
\end{tabular}

Mean \pm SD ( $n=3$ ); One-way ANOVA study followed by Tukey's post test

Significance level, ${ }^{* *} p<0.05$. RuE: Rutin equivalent and thus inhibit oxidative mechanisms that lead to degenerative diseases. ${ }^{41}$ Based on that, the following few methods were studied for the CF fruit pulp extract.

DPPH: The free radical scavenging activity of all crude extracts of the CF fruit pulp was quantitatively determined using a DPPH assay along with $\mathrm{IC}_{50}$ values. $\mathrm{IC}_{50}$ values represent the particular concentration of a test extract that inhibit activity by $50 \%$. The results are tabulated in Figure 7 . The effect of antioxidants on $\mathrm{DPPH}$ is thought to be due to their hydrogen-donating ability. ${ }^{42}$ DPPH is a purple-colored dye with absorption maxima of 517 $\mathrm{nm}$, and upon reaction with a hydrogen donor, the purple color fades or disappears due to its conversion to 2, 2-diphenyl1-picryl hydrazine, and hence absorbance is decreased. The combined aqueous and methanol extracts showed the maximum percentage inhibition (68.43\%), followed by the methanol extract (58.24\%) at $200 \mu \mathrm{g} / \mathrm{mL}$ concentration, whereas L-ascorbic acid showed $92.17 \%$ inhibition. The scavenging activity potency for all the extracts was determined using $I_{50}$ values. The combined extract (aqueous + methanol) showed a lower $\mathrm{IC}_{50}$ value of 42.38 $\mu \mathrm{g} / \mathrm{mL}$, followed by the methanol extract $(52.43 \mu \mathrm{g} / \mathrm{mL}$, Table 8) when compared with standard L-ascorbic acid $(4.87 \mu \mathrm{g} / \mathrm{mL})$.

Hydrogen peroxide radical scavenging assay: Hydrogen peroxide is a weak oxidizing agent, and through oxidation of essential thiol (-SH) groups, it can inactivate a few enzymes. The generation of $\mathrm{H}_{2} \mathrm{O}_{2}$ in minimum quantities in biologic systems is significant to determine. Naturally-occurring iron complexes inside the cell react with $\mathrm{H}_{2} \mathrm{O}_{2}$ in vivo and highly reactive hydroxyl radicals are generated, which cause the origins of toxic effects. ${ }^{43}$

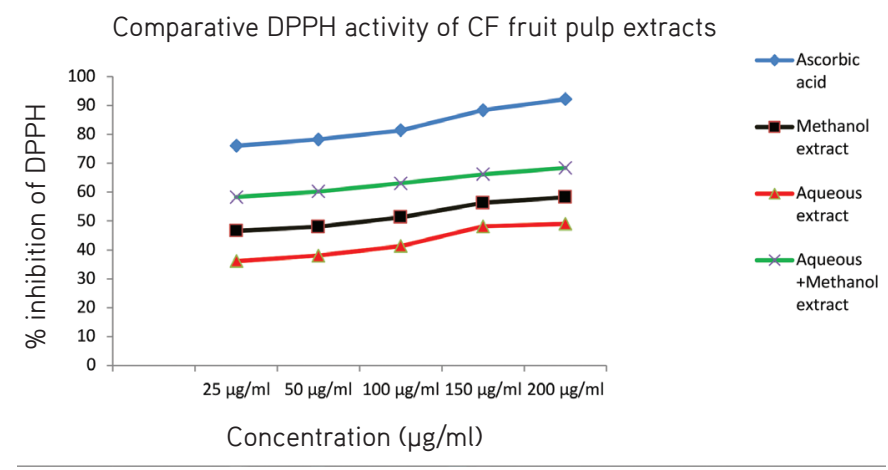

Figure 7. DPPH activity of L-ascorbic acid and various CF fruit extracts Results were triplicate, each values represent mean $\pm S D(n=3)$

Table 8. IC ${ }_{50}$ values of different extracts of CF fruits in DPPH and $\mathrm{H}_{2} \mathrm{O}_{2}$ scavenging assay $\mathrm{IC}_{50} \mu \mathrm{g} / \mathrm{mL}$

\begin{tabular}{lll} 
Extracts & $\begin{array}{l}\text { DPPH scavenging } \\
\text { assay }\end{array}$ & $\begin{array}{l}\text { Hydrogen } \\
\text { peroxide- } \\
\text { scavenging activity }\end{array}$ \\
\hline Methanol & $52.43 \pm 0.024$ & $54.22 \pm 0.014$ \\
\hline Aqueous & $66.21 \pm 0.021$ & $68.28 \pm 0.031$ \\
\hline Aqueous + methanol & $42.38 \pm 0.012$ & $46.80 \pm 0.011$ \\
\hline Ascorbic acid (standard) & $4.87 \pm 0.030$ & $9.18 \pm 0.020$ \\
\hline
\end{tabular}

Results of triplicate tests, Each value represents mean $\pm \operatorname{SD}(n=3)$ 
The scavenging activity of CF fruit extracts was evaluated and compared with ascorbic acid and the results are tabulated in Figure 8. It was reported that $\mathrm{H}_{2} \mathrm{O}_{2}$ scavenging activity of extracts depends on the phenolic content, which can donate electrons to $\mathrm{H}_{2} \mathrm{O}_{2}{ }^{44}$ the present study revealed the content of phenolics showing scavenging activity of $\mathrm{H}_{2} \mathrm{O}_{2}$. Among the three extracts, the combined extract (aqueous + methanol) followed by the methanol extract showed good activity in depleting $\mathrm{H}_{2} \mathrm{O}_{2}$ with $\mathrm{IC}_{50}$ values of 46.80 and $54.22 \mu \mathrm{g} / \mathrm{mL}$, respectively (Table 8). The percentage of $\mathrm{H}_{2} \mathrm{O}_{2}$ scavenging activity of the combined extract was found as $61.07 \%$, followed by the methanol extract (59.23\%) at $200 \mu \mathrm{g} / \mathrm{mL}$ concentration as compared with standard L-ascorbic acid (90.13\%).

Correlation matrix: There is a direct correlation between the percentage yield and the content of secondary metabolites; the antioxidant study was observed in the present investigation.

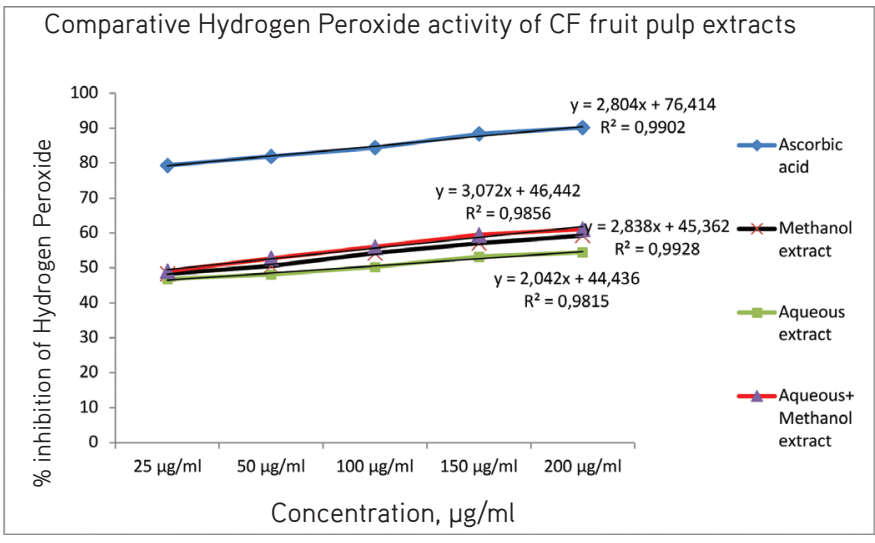

Figure 8. Hydrogen peroxide scavenging activity of L-ascorbic acid and various $\mathrm{CF}$ fruit extracts

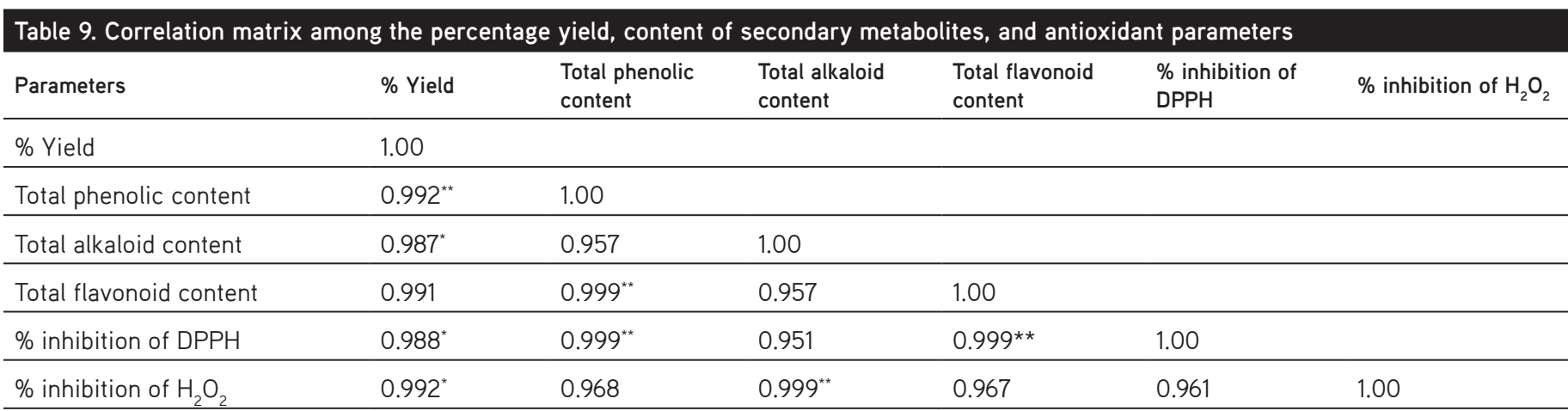

**Significant at $1 \%$; *Significant at $5 \%$

Table 10. Anthelmintic activity of various extracts of CF fruit pulp

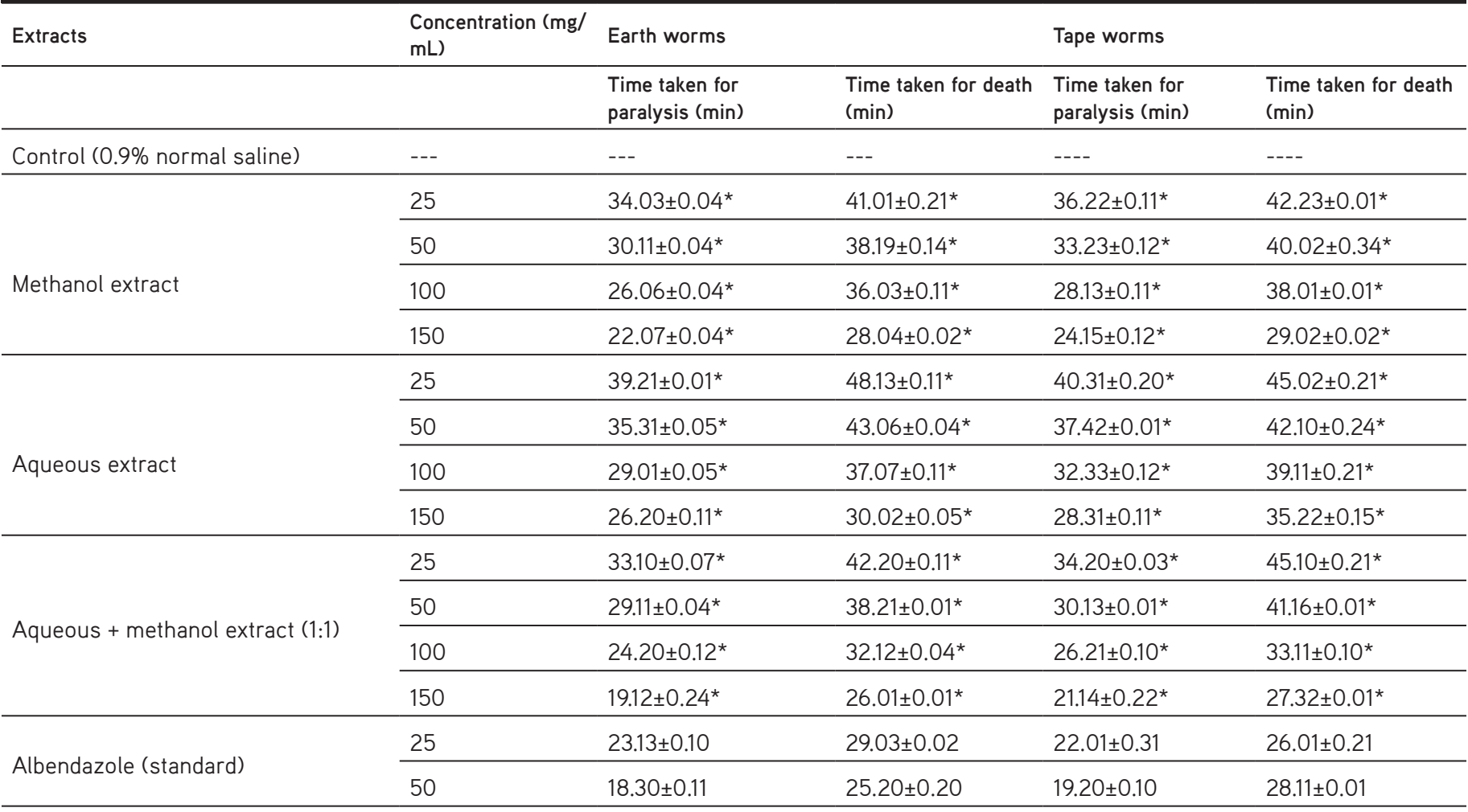

Values are expressed as mean \pm SD. Values were find out by using one-way ANOVA followed by Dunnett's t-test. *Values are significantly different from control at (p<0.05) 
The results are depicted in Table 9.

The results from Table 9 indicate that the percentage yield of extract in particular solvents (CF fruit pulp) has a direct correlation with the content of secondary metabolites and even antioxidant activities. Furthermore, Table 8 indicates that antioxidant activity is dependent on $I_{50}$ values, which are inversely correlated; this result is in agreement with earlier research findings. ${ }^{45}$ Based on the presence of various phytochemicals viz. alkaloids, phenols, tannins, flavonoids and due to the strong antioxidant activity of CF fruit extracts, further anthelmintic activity was tested for the first time. Many scientific studies have already revealed that the presence of phenols, tannins, and flavonoids leads to anthelmintic activity. ${ }^{46,47}$

Anthelmintic activity: Preliminary anthelmintic activity was tested using various extracts of the CF plant on adult earthworms (Pheretima posthuma), followed by tape worms (Taenia solium), at doses of 25,50,100, and $150 \mathrm{mg} / \mathrm{mL}$ and compared with acontrol (0.9\% normal saline) and albendazole (25 $\mathrm{mg} / \mathrm{mL}$ and $50 \mathrm{mg} / \mathrm{mL}$ ) as a standard. The results revealed that the combined aqueous and methanol extract of CF fruit pulp showed significant anthelmintic activity (26.01 min for the death of the worms) compared with the others with respect to paralysis followed by death for earth worms at $150 \mathrm{mg} / \mathrm{mL}$ concentration, and the same combined extract produced death in tape worms at 37.32 min, which was near to the standard drug $(28.11 \mathrm{~min}$ ) (Table 10 ). Table 10 reveals that albendazole at $50 \mathrm{mg} / \mathrm{mL}$ concentration showed 18.30 and $19.20 \mathrm{~min}$ for paralysis and 25.20 and 28.11 min for the death of the earth worms and tape worms, respectively.

A literature review reported that tannins and phenolics were known to interfere with energy generation in parasites with the mechanism of uncoupled oxidative phosphorylation, ${ }^{46}$ and causes death by binding with free proteins in the gastrointestinal tract of the host animal or glycoprotein on the cuticle of the parasite. The estimation of alkaloids, phenolics, and flavonoids in CF fruit extracts resulted with a high content in the combined methanol and aqueous extract, which supported the strong anthelmintic activity. ${ }^{31}$ The result was reported similarly in earlier scientific research. ${ }^{48,49}$ In the present study, earthworms were selected for the preliminary study because they are more sensitive than tape worms and round worms. ${ }^{50}$ Earlier literature established the anthelmintic activity of Coscinium fenestratum stem aqueous extract against round worms and earthworms $\mathrm{s}^{51}$ and death resulted after more than $63 \mathrm{~min}$, whereas in our study, the fruit pulp extract produced death at around $37.32 \mathrm{~min}$, less than stem extract. The result must be due to the effect of the solvent used in extraction.

\section{CONCLUSION}

The present investigation has shown that CF fruit pulp has therapeutic activities due to the presence of secondary metabolites and has significant anthelmintic activity due to estimated total alkaloid, phenol, and flavonoid content. The solvent system played a vital role for the activities in which combined aqueous and methanol extract showed the most significant antioxidant and anthelmintic activity as compared with individual methanol and aqueous extracts. This is the first report on CF fruit pulp extract, which may be further explored for its phytochemical profile to recognize the active constituent responsible for anthelmintic activity.

\section{ACKNOWLEDGEMENTS}

Authors are thankful to Rajiv Gandhi University of Health Sciences, Bangalore, India for financial assistance of Rs. 1.5 Lakhs as research grant (Principal Investigator) for carry out the present investigation (Order No. RGU: Adv. Res.: Proposal-P-171: 2015-16 DATE: 06-01-2016).

Conflict of Interest: No conflict of interest was declared by the authors.

\section{REFERENCES}

1. Hyun DH, Hernandez JO, Mattson MP, de Cabo R, The plasma membrane redox system in aging. Ageing Res Rev. 2006;5:209-220.

2. Sas K, Robotka H, Toldi J, Vecsei L, Mitochondrial, metabolic disturbances, oxidative stress and kynurenine system, with focus on neurodegenerative disorders, J Neurol Sci. 2007;257:221-239.

3. Hotez PJ, Brindley PJ, Bethony JM, King CH, Pearce EJ, Jacobson J. Helminth infections: the great neglected tropical diseases. J Clin Invest. 2008;118:13111321.

4. Mulla WA, Thorat VS, Patil RV, Burade KB, Anthelmintic activity of leaves of Alocasia indica Linn, International Journal of PharmTech Research. 2010;2:2630.

5. Tushar KV, George S, Remashree AB, Balachandran I, Coscinium fenestratum (Gaertn.) Colebr.-A review on this rare, critically endangered and highlytraded medicinal species. Journal of Plant Science. 2008;3:133-145.

6. Karunarathne $\mathrm{V}$, The rich diversity and the potential medicinal value of the Sri Lankan Flora. Phyta. 2001;5:23-24.

7. Remashree AB, Jayanthi A, Thushar KV, Ravindran PN, Balachandran I. Anatomy of Coscinium fenestratum (Gaertn.) Colebr. A critically endangered medicinal plant from Western Ghats. Phytomorphology. 2005;55:249-258.

8. Sumy O, Ved DK, Krishnan R. Tropical Indian Medicinal Plants: Propagation methods. Bangalore India; FRLHT; 2000:114-115.

9. Rai RV, Rajesh PS, Kim HM, Medicinal use of Coscinium fenestratum (Gaertn.) Colebr: a short review. Oriental Pharmacy and Experimental Medicine. 2013;13:1-9.

10. Udayan PS, George S, Tushar KV, Balachandran I. Medicinal plants used by the Kaadar tribes of Sholayar forest, Thrissur district, Kerala. Indian Journal of Traditional Knowledge. 2005;4:159-163.

11. Udayan PS, George S, Tushar KV, Balachandran I. Ethnomedicinal plants used by the Oorali tribe of Idukki district, Kerala state, India. Journal of Economic and Taxonomic Botany. 2005;29:219-220.

12. Agusta A. Coscinium fenestratum (Gaertner) Colebr. In: Lemens RMHJ, Bunyapraphatsara N, eds. Plant Resources in South East Asia; Medicinal and Poisonous Plants; 2003;3:139-140.

13. Warakagoda PS, Subasinghe S. Studies on seed germination of Coscinium fenestratum (Menispermaceae): A threatened medicinal plant. International Journal of Minor Fruits, Medicinal and Aromatic Plants. 2015;1:37-46.

14. Goveas SW, Abraham A, Evaluation of antimicrobial and antioxidant activity of stem and leaf extracts of Coscinium fenestratum, Asian J Pharm Clin Res. 2013;6:218-221.

15. Birdsall TC. Berberine: Therapeutic potential of an alkaloid found in several medicinal plants. Alternative Medicine Review. 1997;207:94-103. 
16. Nayak A, Sajini RJ, Padmavati D, Karthik R, Chemistry and Medicinal Properties of Coscinium fenestratum (Gaertn.) Colebr (Tree Turemric), Research Journal of Pharmacy and Technology. 2012;5:198-202.

17. Madhavan SC, Bose C, Perakathusseril TM, Banerji A. Indian medicinal plant, Coscinium fenestratum- A new bio source for the multifunctional bio active molecule-ecdysterone. International Journal of Herbal Medicine. 2014;2:5-9.

18. Malu SP, Obochi GO, Edem CA, Nyong BE. Effect of methods of extraction on phytochemical constituents and antimicrobial properties of Tetracarpidium conophorum seeds. Global J of Pure and Applied Sciences. 2009;15:373-376.

19. Das K. Phytochemical evaluation and comparative antibiocide efficacy of Aqueous, Ethanolic and equal mixture of aqueous and ethanolic (1:1) bark extract of Lannea coromandelica L. procured from Eastern region of India. International Letters of Natural Sciences. 2014;26:21-31.

20. Orhan IE, Atasu E, Senol FS, Ozturk N, Demirci B, Das K, Sekeroglu N. Comparative studies on Turkish and Indian Centella asiatica (L.) Urban (gotu kola) samples for their enzyme inhibitory and antioxidant effects and phytochemical characterization. Industrial Crops and Products. 2013;47:316322.

21. Khandelwal KR. Practical Pharmacognosy Techniques and Experiments. Nirali Prakashan; Pune; 2003.

22. Kokate CK. Practical Pharmacognosy. Vallabh prakashan; Delhi; 2005:107-111.

23. Shamsa $F$, Monsef $H$, Ghamooshi $R$, Verdian-rizi M. Spectrophotometric determination of total alkaloids in some Iranian medicinal plants. Thai $\mathrm{J}$ Pharm Sci. 2008;32:17-20.

24. Kim DO, Jeong SW, Lee CY, Antioxidant capacity of phenolic phytochemicals from various cultivars of plums. Food Chemistry. 2003;81:321-326.

25. Park YS, Jung ST, Kang SG, Heo BK, Avila- Arancibia P, Toledo F, Drzewiecki J, Namiesnik J, Gorinstein S. Antioxidants and proteins in ethylene-treated kiwifruits. Food Chemistry. 2008;107:640-648.

26. Brand-Williams W, Cuvelier ME, Berset C. Use of free radical method to evaluate antioxidant activity. LWT-Food Science and Tecnology. 1995;28:2530.

27. Nabavi SM, Ebrahimzadeh MA, Nabavi SF, Fazelian M, Eslami B, In vitro antioxidant and free radical scavenging activity of Diospyros lotus and Pyrus boissieriana growing in Iran. Pharmacognosy Magazine. 2009;5:122-126.

28. Ajaiyeoba EO, Onocha PA, Olarenwaju OT. In vitro anthelmintic properties of Buchholziacoriaceae and Gynandropsis gynandra extract. Pharmaceutical Biology. 2001;39:217-220.

29. Chandrashekhar $\mathrm{CH}$, Latha KP, Vagdevi HM, Vaidya VP, Anthelmintic activity of the crude extracts of Ficus racemosa. International Journal of Green Pharmacy. 2008;2:100-103.

30. Das K, Tribedi S. Effect of Zn, Fe and Cu Content on Phytochemical Investigations and Antimicrobial Potential of Alternanthera brasiliana (L.) 0. Kuntze Leaf Extracts Procured From Two Different States of India. Turk J Pharm Sci. 2015;12:345-356.

31. Do QD, Angkawijaya AE, Tran-Nguyen PL, Huynh LH, Soetaredjo FE, Ismadji $\mathrm{S}$, Ju YH. Effect of extraction solvent on total phenol content, total flavonoid content, and antioxidant activity of Limnophila aromatic. J Food Drug Anal. 2014:22:296-302.

32. Sultana B, Anwar F, Ashraf M. Effect of extraction solvent/technique on the antioxidant activity of selected medicinal plant extracts. Molecules. 2009;14:2167-2180.

33. Das K, Rekha R, Yahya Ahmed S, Raman Dang. Effect of seasonal variation and solvent systems on estimation of phytochemicals and screening of anthelmintic activity of Kydia calycina Roxb. Leaf. Advances in Biomedicine and Pharmacy. 2016;3:358-365.
34. Mohsen MS, Ammar SMA. Total phenolic contents and antioxidant activity of corn tassel extracts. Food Chemistry. 2008;112:595-598.

35. Zhou K, Yu L. Effects of extraction solvent on wheat bran antioxidant activity estimation. LWT-Food science and Technology. 2004;37:717-721.

36. Gao M, Liu CZ. Comparison of techniques for the extraction of flavonoids from cultured cells of Saussurea medusa Maxim. World Journal of Microbiology and Biotechnology. 2005;21:1461-1463.

37. Okudu T, Yoshida T, Hatano T. Food phytochemicals for cancer prevention II. In: Ho CT, Osawa T, Huang MT, Rosen RT, eds. Chemistry and antioxidative effects of phenolic compounds from licorice, tea and Compositae and Labiateae herbs, Washington; DC: American Chemical Society; 1994:132-143.

38. Tepe B, Sokmen M, Akpulat HA, Sokmen A. Screening of the antioxidant potentials of six Salvia species from Turkey. Food Chemistry. 2006;95:200204.

39. Zheng W, Wang SY. Antioxidant activity and phenolic compounds in selected herbs. J Agric Food Chem. 2001;49:5165-5170.

40. Yamagishi S, Matsui T, Nitric oxide, a Janus-faced therapeutic target for diabetic microangiopathy-Friend or foe? Pharmacol Res. 2011;64:187-194.

41. Wu YY, Li W, Xu Y, Jin EH, Tu YY, Evaluation of the antioxidant effects of four main the aflavin derivatives through chemiluminescence and DNA damage analyses. Jf Zhejiang Univ Sci B. 2011;12:744-751.

42. Baumann J, Wurn G, Bruchlausen FV, Prostaglandin synthetase inhibiting 0-2 radical scavenging properties of some flavonoids and related phenolic compounds. Deutsche Pharmakologische Gesellschaft Abstracts of the 20th spring meeting, Naunyn-Schmiedebergs Abstract No: R27 cited in Arch Pharmacol. 1979;307:R1-R77.

43. Miller HE, Rigelhof F, Marquart L, Prakash A, Kanter M. Antioxidant Content of Whole Grain Breakfast Cereals, Fruits and Vegetables. J Am Coll Nutr. 2000;19(Suppl 3):312-319.

44. Ebrahimzadeh MA, Nabavi SF, Nabavi SM. Antioxidant activities of methanol extract of Sambucus ebulus L. flower, Pak J Biol Sci. 2009;12:447-450.

45. Mun-Seow H, Amru Nasrulhaq B, Chandran S. Antioxidant activity, phenolic and flavonoid contents in the leaves of different varieties of sweet potato (Ipomoea batatas). Australian Journal of Crop Science. 2012;6:375-380.

46. Athnasiadou S, Kyriazakis I, Jackson F, Coop RL, Direct anthelmintic effects of condensed tannins towards different gastrointestinal nematodes of sheep: in vitro and in vivo studies. Vet Parasitol. 2001;99:205-219.

47. Adeniran AA, Sonibare MA. In vitro potential anthelmintic activity of bulbils of Dioscorea bulbifera L. on earthworms and liverflukes. J Pharmacognosy Phytother. 2013;5:196-203.

48. Nayak S, Chakraborti CK, Jaiswal P, Sah UK, Mohanta DSD. Correlation between the phytochemical constituents and anthelmintic activity of Lawsonia inermis leaf extracts. IJRAP. 2012;3:559-562.

49. Das K, Deb S, Karanth T, Upreti S, Dang R. Effect of cultural condition on element contents in raw material vis-à-vis impact of solvent nature on estimation of phytochemicals and screening of anthelmintic activity of Melia dubia Cav. leaf, Annals of Phytomedicine. 2016;5:58-68.

50. Dewanjee S, Maiti A, Kundu M, Mandal SC. Evaluation of anthelmintic activity of crude extracts of Diospyros peregrina, Coccinia grandis and Schima wallichii. Dhaka Univ J Pharm Sci. 2007;6:121-123.

51. Kekuda TR P, Naaz S, Sushma BL, Sudharshan SJ, Murthuza S. In vitro studies on anthelmintic activity of modern drugs and aqueous extracts of curcuma aromatica and Coscinium fenestratum. BTAIJ. 2008;2:86-89. 